Sprawozdania / Reports

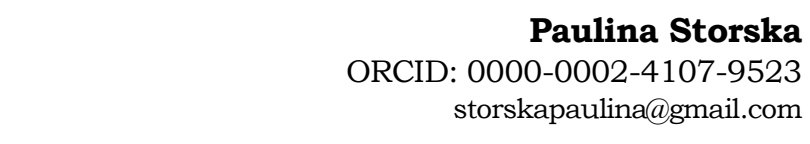

Uniwersytet Przyrodniczo-Humanistyczny w Siedlcach Wydział Nauk Społecznych

\title{
I Ogólnopolska Studencko-Doktorancka Konferencja Kół Naukowych „Wyzwania bezpieczeństwa na początku trzeciej dekady XXI w.", Siedlce 24 września 2020 r.
}

DOI: $10.34739 /$ doc.2020.17.23

W dniu 24 września 2020 r. w Uniwersytecie PrzyrodniczoHumanistycznym w Siedlcach na Wydziale Nauk Społecznych w Instytucie Nauk o Bezpieczeństwie odbyła się I Ogólnopolska Studencko-Doktorancka Konferencja Kół Naukowych pt. „Wyzwania bezpieczeństwa na początku trzeciej dekady XXI w." Została ona zorganizowana przez Koło Naukowe Doktorantów Nauk o Bezpieczeństwie UPH we współpracy ze Studenckim Kołem Naukowym Bezpieczeństwa Narodowego UPH. W skład Komitetu Naukowego Konferencji wchodzili: dr hab. Mariusz Kubiak, profesor uczelni (przewodniczacy), dr hab. Henryk Wyrębek, profesor uczelni, dr Paweł Szmitkowski, mgr Mateusz Matejuk. Natomiast Komitet Organizacyjny tworzyli: mgr Mateusz Matejuk, mgr Wojciech Krasińki, mgr Przemysław Mazurczak, mgr Grzegorz Czapski, Jacek Ostat, Joanna Krupa, Dominika Jastrzębska, Karol Piotrowski, Adrianna Juszczuk.

W czasie obrad omawiano zagadnienia dotyczace szeroko pojmowanego bezpieczeństwa. Konferencja stała się elementem interdyscyplinarnego dyskursu nad wyzwaniami bezpieczeństwa w trzeciej dekadzie XXI w. Podczas obrad zrealizowano następujące cele: 
I. Identyfikacja wyzwań bezpieczeństwa i związanych z nimi dylematów decyzyjnych, przed którymi stoją różnego rodzaju podmioty na początku trzeciej dekady XXI w.

II. Porównanie i analiza aktualnych wyzwań bezpieczeństwa w perspektywie wyzwań minionych dekad.

III. Ocena perspektyw radzenia sobie $z$ wyzwaniami poprzez poszczególne podmioty bezpieczeństwa w skali lokalnej, krajowej, regionalnej i globalnej.

IV. Prognozowanie nadchodzacych wyzwań.

Omawiane podczas konferencji zagadnienia sięgały obszarów poznawczych wielu dyscyplin naukowych. Istotne jest, aby zagadnienie bezpieczeństwa było postrzegane multidyscyplinarnie. Podejmowane w tym obszarze dyskusje winny uwzględniać także różne konteksty i źródła informacji. Tylko wtedy możliwe jest pełne zobrazowanie sytuacji i analiza zagadnienia. W konferencji zaplanowano 95 wystapień $z$ udziałem 101 prelegentów. Udało się przedstawić 91 prezentacji zrealizowanych przez 97 uczestników. Ciekawym rozwiązaniem $\mathrm{w}$ zwiąku $\mathrm{z}$ ograniczeniami epidemiologicznymi było to, iż konferencja odbyła się w formie zdalnej $z$ wykorzystaniem komunikacji online. Dało to możliwość nie tylko wysłuchania wszystkich wystąpień, ale także przeprowadzenia dyskusji w czasie rzeczywistym.

Podczas konferencji głos zabrali przedstawiciele reprezentujący 28 krajowych ośrodków naukowych. Wygłoszone referaty dotyczyły między innymi takich zagadnień, jak bezpieczeństwo jako wartość, rola Unii Europejskiej w zapewnieniu bezpieczeństwa, bezpieczeństwo regionalne, współczesne zagrożenia, a także aktualna problematyka dla bezpieczeństwa, jaka stanowia kwestie zwiazane w epidemia koronawirusa SARS-CoV-2 (Covid-19). Szczególnie to zagadnienie było bliskie uczestnikom konferencji bowiem, jak oceniano, ma wpływ nie tylko na bezpieczeństwo, ale także na życie codzienne wszystkich ludzi. Omawiana problematyka koncentrowała się na różnych znaczeniach pojęć „bezpieczeństwo" i „wyzwania”, w odniesieniu do ich stanu obecnego, perspektyw, a także kwestii skutków. Na konferencji przedstawiono zarówno dane historyczne, stan aktualny, jak i prognozy, skupiając się przede wszystkim na perspektywie trzeciej dekady XXI w. 
Konferencja rozpoczęła się wystapieniem dr inż. Michała Kruszyńskiego z Międzynarodowej Wyższej Szkoły Logistyki i Transportu we Wrocławiu. Przedstawił on referat Bezpieczeństwo żywnościowe państwa - współczesne wyzwania. Kolejne wystapienie - Piotra Żaka $z$ Uniwersytetu Jagiellońskiego - dotyczyło zagadnienia Europy i wojny - czy lata 20. XXI w. będa wolne od konfliktów militarnych na Starym Kontynencie?. Następnie Mateusz Danielewski z Uniwersytetu Warszawskiego zaprezentował problem Program nuklearny Koreańskiej Republiki Ludowo-Demokratycznej-wyzwanie czy „temat zastępczy" dla polityki bezpieczeństwa mocarstw?. Wojciech Maksymiuk z Uniwersytetu Przyrodniczo-Humanistycznego w Siedlcach wystapił $\mathrm{z}$ referatem Istota $i$ charakter wspókczesnego fundamentalizmu religijnego jako zagrożenia dla bezpieczeństwa międzynarodowego. Kolejna prezentację - Bezpieczeństwo i prawa człowieka: scenariusz tykajacej bomby 20 lat po 11 września 2001 r. przedstawił Przemysław Brzuszczak z Uniwersytetu Warszawskiego / Szkoły Głównej Handlowej w Warszawie. Pacyfizm jako postulat polityczny. Wplyw partii pacyfistycznych na bezpieczeństwo $w$ Europie Środkowej zaprezentował Cezary Paprzycki, przedstawiciel Uniwersytetu im. Adama Mickiewicza w Poznaniu. Artur Janczuk ze Szkoły Głównej Handlowej w Warszawie przedstawił referat Bezpieczeństwo polityczne - niedoceniana kategoria?, zaś Justyna Jarocka $z$ Uniwersytetu $\mathrm{w}$ Białymstoku zaprezentowała zagadnienie Bezpieczeństwo jako wartość konstytucyjna usprawiedliwiajaca ograniczenie praw $i$ wolności jednostki. Następnie uczestnicy mogli zapoznać się $z$ referatem Ponadczasowość zasad etyki zawodu adwokata a granice dozwolonego działania $w$ polskim prawie karnym, który został zaprezentowany przez Katarzynę Mróz z Uczelni Łazarskiego w Warszawie. Kolejne wystapienie Bezpieczeństwo energetyczne w Unii Europejskiej-aspekt prawny zostało przeanalizowane przez Małgorzatę $\mathrm{Ku}-$ czerę $z$ Uniwersytetu Kardynała Stefana Wyszyńskiego w Warszawie. Następne zagadnienie, przedstawione przez Dominikę Czaplę z Uniwersytetu Warszawskiego, także odnosiło się do Unii Europejskiej i pozwoliło przybliżyć Role Unii Europejskiej w zapewnieniu bezpieczeństwa na Bliskim Wschodzie. Analiza aktualnych zagrożen dla bezpieczeństwa na obszarze poradzieckim została zaprezentowana przez Joannę Bagadzińską z Uniwersytetu Warszawskiego / 
Uniwersytetu im. Adama Mickiewicza w Poznaniu, zaś Technologiczna rywalizacja Chin $i$ USA przez Ernesta Szymalę z Uniwersytetu Warszawskiego / Szkoły Głównej Handlowej. Kolejny temat Przestępstwa popetnione $w$ cyberprzestrzeni, a prawo do anonimowości, aspekty prawne zaprezentował Tomasz Bojanowski $z$ Uniwersytetu Kardynała Stefana Wyszyńskiego w Warszawie. Karolina KamińskaSurówka $z$ Uniwersytetu w Białymstoku przedstawiła temat Zjawisko „kradzieży tożsamości” $w$ Internecie - wyzwania bezpieczeństwa. Bartosz Dzikowski z Politechniki Warszawskiej przybliżył słuchaczom zagadnienie bezpieczeństwa $\mathrm{w}$ sieci, prezentując referat Czy Obama rozdaje bitcoiny? - czyli o bezpieczeństwie kont $w$ Internecie. Na zakończenie pierwszego panelu Aleksandra Urbanowicz z Katolickiego Uniwersytetu Lubelskiego Jana Pawła II przedstawiła prezentację na temat Ocena reformy polskiej armii w ujęciu szkoleniowym na przestrzeni ostatnich lat pod katem wyzwań bezpieczeństwa. Dalsze obrady zostały podzielone na cztery równoległe panele problemowe. Na każdym $z$ nich wystąpiło 18 prelegentów. Poszczególne panele wieńczyła dyskusja, podczas której uczestnicy mogli wymieniać się swoimi spostrzeżeniami na temat wszystkich wystąpień.

Moderatorem panelu pierwszego był Mateusz Matejuk. Podczas obrad poruszano tematy zwiazane $z$ bezpieczeństwem dzieci $\mathrm{w}$ szkole oraz przedszkolu, technologiami w edukacji, procesem nauczania. Prelegenci skupili się przede wszystkim na nowych formach nauczania i nowej rzeczywistości szkolnej, która jest wyzwaniem zarówno dla instytucji szkolnych, jak i dla dzieci i młodzieży szkolnej. W czasie obrad panelu przedstawiono między innymi takie tematy, jak: Bezpieczeństwo w przedszkolu - edukacja przedszkolna wobec wyzwań XXI w. (Agnieszka Wierzchosławska - Uniwersytet Kazimierza Wielkiego w Bydgoszczy), Organizacja procesu nauczania $w$ placówkach oświatowych podczas pandemii COVID-19 w Polsce i Ukrainie (Kateryna Stashuk - Państwowa Szkoła Wyższa im. Papieża Jana Pawła II w Białej Podlaskiej), Wiedza i opinia rodziców w zakresie środków bezpieczeństwa, wprowadzonych $w$ szkołach podstawowych z powodu zagrożenia epidemicznego (Miłosława Szupiluk - Akademia Pedagogiki Specjalnej im. Marii Grzegorzewskiej 
w Warszawie). Dodatkowo prezentowano także zagadnienia zwiazane $z$ bezpieczeństwem społecznym.

Panel drugi stał się płaszczyzna obrad zwiazanych $z$ bezpieczeństwem zdrowotnym, bezpieczeństwem żywnościowym, a także tematyka militarną. Moderatorem panelu był Radosław Kondracki, który dbał o jego właściwy przebieg. Zaprezentowano między innymi takie tematy, jak: Wyzwania dla Marynarek Wojennych Siwiata $w$ przypadku walk hybrydowych $i$ asymetrycznych na bazie doświadczeń $z$ dotychczasowych operacji (Wiktor Stypczyński - Uniwersytet im. Adama Mickiewicza w Poznaniu), Bezpieczeństwo zdrowotne jako wyzwanie na poczatku trzeciej dekady XXI w. (Joanna Kielmas - Uniwersytet Przyrodniczo-Humanistyczny w Siedlcach), Bezpieczeństwo i problemy pacjentów onkologicznych $w$ dobie pandemii COVID-19 (Michalina Pytka, Aleksandra Żywicka, Piotr Jarosz Uniwersytet Medyczny w Lublinie), Bezpieczeństwo żywnościowe $w$ Polsce (Sebastian Krasuski - Uniwersytet Przyrodniczo-Humanistyczny w Siedlcach). Podobnie jak podczas poprzedniego panelu, wszystkie tematy dotykały bieżących wyzwań bezpieczeństwa. Wskazywały one na trudności, z jakimi muszą się borykać współczesne państwa, przede wszystkim zaś Polska.

Nad przebiegiem wystapień panelu trzeciego czuwały Dominika Jastrzębska oraz Adrianna Juszczuk. Podczas obrad poruszono zagadnienia dotyczące bezpieczeństwa finansowego, sektora bankowego, funkcjonowania przedsiębiorstw. Wśród tematów wskazać można między innymi następujące: Istota bezpieczeństwa finansowego (Karolina Magnuszewska - Uniwersytet Przyrodniczo-Humanistyczny w Siedlcach), System podatkowy a bezpieczeństwo ekonomiczne państwa (Paulina Grodzka, Agnieszka Modzelewska - Uniwersytet w Białymstoku), COVID-19 $w$ miejscu pracy a obowiazek zapewnienia przez pracodawce bezpieczeństwa i higieny pracy. Jak koronawirus wpłynat na instytucje i zasady prawa pracy? (Krzysztof Dziadosz, Magdalena Kurnatowska - Uniwersytet im. Adama Mickiewicza w Poznaniu), Przywództwo wXXI w. (Aleksandra Surma - Uniwersytet Marii Curie-Skłodowskiej w Lublinie).

Panel czwarty moderowany był przez Przemysława Mazurczaka. Prelegenci odnosili się do nowych zagrożeń, zwiąanych $z$ cyberprzestrzenia. Wskazywali na takie problemy, jak cyberprze- 
stępczość, rozwój technologii, ochrona danych w sieci. Wśród tematów wskazać zaś można m.in.: Zarzadzanie bezpieczeństwem narodowym - trendy $w$ cyberbezpieczeństwie (Justyna Bartoszuk - Uniwersytet Przyrodniczo-Humanistyczny w Siedlcach), Służby specjalne - współczesne wyzwania cywilizacyjne i technologiczne (Natalia Magnuszewska, Uniwersytet Przyrodniczo-Humanistyczny w Siedlcach), Globalny konstytucjonalizm a cyberbezpieczeństwo (Amanda Dziubińska - Uniwersytet Warszawski), Cyberprzestępczość na poczatku trzeciej dekady XXI w. (Mateusz Powierza - Uniwersytet Przyrodniczo-Humanistyczny w Siedlcach).

Podczas konferencji przedstawiciele różnych instytucji naukowych oraz środowisk dokonywali prezentacji badań $z$ zakresu współczesnych wyzwań bezpieczeństwa. Zjawiska te przedstawiono zarówno w szerokim, jak i wąskim ujęciu. Prelegenci uwzględnili szanse oraz wyzwania, a także zagrożenia, co pozwoliło na określenie najważniejszych zagadnień zwiazanych $z$ tematyką. Osoby występujące nie były obojętne wobec tak ogromnego wyzwania, jakim jest obecnie walka $z$ pandemia COVID-19. Tematyka ta dotyczy wszystkich ludzi zarówno od strony bezpieczeństwa, jak i życia codziennego. Młodzi naukowcy trafnie potrafili wskazać, jakie sfery zostały najbardziej dotknięte zmianami, a także, które $z$ nich moga w przyszłości być narażone na trudne konsekwencje. I tak też warto wspomnieć, iż nowa rzeczywistość obejmuje także życie i działalność studencka, co można było zaobserwować również przez formę prowadzenia konferencji, która odbyła się zdalnie. Prelegenci nie tylko zdefiniowali współczesne wyzwania bezpieczeństwa, ale także określili, w jaki sposób można przeciwstawiać się pojawiajacym się zagrożeniom. Podczas konferencji podjęto próby uzyskania odpowiedzi na wiele pytań, stawianych w obszarze bezpieczeństwa. Stoi to w zgodzie $z$ jej założeniami, o których podczas otwarcia konferencji wspominał przewodniczacy Komitetu Organizacyjnego, mgr Mateusz Matejuk mówiąc, że „(...) w kontekście obecnie pojawiających się wyzwań niezwykle ważna jest ich identyfikacja, analiza i popełnienie stosownych refleksji". Zaprezentowane wystapienia interesujaco wpisały się w nakreślony cel konferencji. Spotkanie było niewątpliwie dla uczestników ważnym forum wymiany poglądów. 